\title{
THE COLONIES AND FOREST ADMINISTRATION
}

\author{
By Prof. E. P. Stebbing
}

$\mathrm{I}^{\mathrm{H}}$ his Annual Forest Administration Report for 1938* the Conservator of Forests, Trinidad and Tobago, summarizes the forest policy in force. The clauses merit repeating here, for though they have been current in forest management in the British Empire for several decades, they have often proved to be pious platitudes rather than a carefully thought-out planning to which the Government concerned intended to adhere rigidly. The clauses are :

"(1) The permanent reservation by the Crown of suitably situated areas of forest of a total acreage sufficient to supply the benefits necessary for the welfare of the community-indirect benefits in the form of the maintenance of climatic conditions for agricultural crops, preservation of water supply, prevention of erosion and flooding, and so on, and direct benefits in the form of the supply of forest produce. (2) The management of these forests in such a way as to encourage the fullest possible utilization of their products on the basis of a sustained yield. (3) Such improvement of the existing growing stock as will enable the Colony in the future to become at least self-supporting in lumber."

There is nothing now in this. It may be found in one form or another in the forest reports and memoranda of every Colony. In the past, how much of these praiseworthy aims has been effected ? It may bo admitted that the Forestry Department in Trinidad in the past decado or so has received support from the Government which has enabled progress to be made in a correct forest administration. But even here the forestry question appears to be regarded not as a whole but as applying to parts of the country only. It is said that the general position with regard to forest reservation is eminently satisfactory except in the western portion of the Northern Range. In this district apparently the greater part of the land area has for many years been under private ownership, and until recently was mainly covered by cacas, forest or second growth. The Conservator, on the subject of this area, continues as follows :

"In the present depressed state of cocoa, land owners are renting out increasing areas of steep hillsides to agricultural peasants, who grow field crops, such as maize, tomatoes, etc., thereon, under a system of shifting cultivation. These peasants prefer the highest, steepest, and most inaccessible portions of the hillsides, as the danger of loss of crops by praedial larceny is thereby lessened. The abnormally high rainfall of 1938 , coupled with the increase of clearings, was productive of erosion, flooding and landslides to an unusual degree, and revealed clearly the dangers of the existing situation. The problem is under investigation by the Lands Advisory Committee."

This description might equally apply, taking local conditions into consideration, to parts of West or East Africa, the Malay States, the Dominion of South Africa, and elsewhere.

Council Paper No. 48 of 1939. (Trinidad: Government Printer, 1939.)
It is admitted that the utilization of local forest produce in Trinidad has not reached by a long way the maximum production permissible, either in the more or less pure mora (Mora excelsa) forests or in the natural mixed forests of the Colony. In the latter the complaint is made that the high cost of exploitation, owing to their small volume-production per acre of marketable species, is a factor contributing to the Colony's dependence upon imported soft woods. From a perusal of the report it would at first sight appear that this latter was a new problem. But it is one which has been in the past, and is at the present day, facing the forester in charge of tropical broad. leaved forests the world over. It is the business and duty of the trained forest staffs to devise methods of successfully dealing with this problem. But they require their Government to have a fixed forest policy, to maintain an adequate forest staff not subject to repeated fluctuations, and to make available adequate grants of money for development.

During the War of 1914-18, the Colonies and their forest services wero offered a great opportunity. Imports of foreign timbers, chiefly softwoods, were cut off. They had to depend upon their own resources. Most of them realized their own weakness and incapacity owing to the paucity of their forestry staffs. These have been considerably strengthened since then, though in many cases they fall far short of what is required.

The Colonies are now offered a second chance. It may bo suggested that the work which should be required from the forestry staffs in all the Colonies during the continuance of the war should proceed on two main lines: (a) Map and report all areas in the Colony subject to any and all forms of erosion, whether forest or agricultural (that is, in the form of shifting cultivation); (b) carry out an enumeration survey or stock mapping in all forests accessible, and likely to bo accessible by means of a grant to open out communications, on a 5 per cent enumeration basis, of such species and only such species as from their locally known qualities are likely to prove saleable, over and above the timber species already of marketable value.

This work of primary importance to the Colony concerned has not been carried out in a detailed and concentrated manner, as is well known. The finance departments of the Colonics have not been able to see beyond the annual revenue produced from the forests; the staff have frittered timo away over this revenue-hunting business; or in experiments with small areas of plantations, fuel and otherwise, neces. sary as this work may have been; and so forth. Since the War of 1914-18, a quarter of a century has passed and but small progress in the correct conservancy of its forest estates has been mado by the Colonial administration as a whole. They are now given a second chance, with all the advantages of having clearly before them the opportunity lost twenty-five years and more ago. Will they profit by the lesson of the past and take it ? 